Abstracta Iranica Abstracta Iranica

Revue bibliographique pour le domaine irano-aryen

Volume 25 | 2004

Comptes rendus des publications de 2002

\title{
«Une liste du calendrier zoroastrien en pehlevi tardif ». Orientalia Suecana, LI-LII (2002-2003), pp. 161-163.
}

Rika Gyselen

\section{(2) OpenEdition}

Journals

Édition électronique

URL : http://journals.openedition.org/abstractairanica/4091

DOI : 10.4000/abstractairanica.4091

ISSN : 1961-960X

Éditeur :

CNRS (UMR 7528 Mondes iraniens et indiens), Éditions de l'IFRI

Édition imprimée

Date de publication : 15 mai 2004

ISSN : 0240-8910

Référence électronique

Rika Gyselen, « « Une liste du calendrier zoroastrien en pehlevi tardif ». Orientalia Suecana, LI-LII

(2002-2003), pp. 161-163. », Abstracta Iranica [En ligne], Volume 25 | 2004, document 23, mis en ligne le 15 mars 2006, consulté le 25 septembre 2020. URL : http://journals.openedition.org/ abstractairanica/4091 ; DOI : https://doi.org/10.4000/abstractairanica.4091

Ce document a été généré automatiquement le 25 septembre 2020.

Tous droits réservés 


\section{«Une liste du calendrier zoroastrien} en pehlevi tardif ». Orientalia Suecana, LI-LII (2002-2003), pp. 161-163.

\section{Rika Gyselen}

1 Ce type de littérature est connu, entre autres, en sogdien, mais est rare en moyenperse. C'est sur un parchemin dans la collection du Bancroft Library de l'université de Berkeley que l'auteur a découvert un tel texte comportant les noms des douze mois du calendrier zoroastrien et la liste fragmentaire des noms de jours.

INDEX

Thèmes : 2.1. Langues anciennes

\section{AUTEURS}

RIKA GYSELEN

CNRS - Paris 